\title{
PROFIL SASTRAWAN KAMPUS UNIVERSITAS NEGERI YOGYAKARTA
}

\author{
Suminto A Sayuti, Else Liliani, dan Kusmarwanti \\ Fakultas Bahasa dan Seni Universitas Negeri Yogyakarta \\ email: suminto_sayuti@uny.ac.id
}

\begin{abstract}
ABSTRAK
Kampus berfungsi tidak hanya sebagai jembatan untuk mencapai pendidikan tinggi, namun juga wahana untuk mengembangkan kompetensi individu, termasuk dalam bidang sastra. Sastrawan-sastrawan muda atau yang bertumbuh ketika menempuh pendidikan di perguruan tinggi atau kampus ini biasa disebut sastrawan kampus. Penelitian ini bertujuan mengidentifikasilatar belakang sosial, ideologi, profesionalisme kepengarangan, dan posisi sosial sastrawan kampus FBS UNY dalam khasanah sastra Indonesia. Penelitian ini menggunakan pendekatan fenomenologis dengan fokus penelitian pada sastrawan kampus yang aktif menulis prosa (novel dan cerpen) di FBS UNY. Hasil penelitian sebagai berikut. Pertama, sastrawan kampus UNY sebagian besar berasal dari suku Jawa. Sastrawan kampus lebih banyak didominasi lelaki. Umumnya, sastrawan kampus memiliki latar belakang keluarga yang berkorelasi dengan dunia pendidikan. Kedua, sastrawan kampus umumnya lebih memilih memperhatikan hal-hal yang dianggap sering diabaikan dalam kehidupan untuk ditulis dalam karya mereka. Idealisme mengenai nilai-nilai otentik yang berbenturan dengan nilai pragmatisme masyarakat menjadi energi besar yang menggerakkan sastrawan-sastrawan kampus untuk menulis. Ketiga, sastrawansastrawan kampus umumnya tidak menjadikan menulis sebagai profesi utama mereka. Menulis adalah kerja sampingan. Sastrawan kampus tidak bergantung pada patronase tertentu. Keempat, beberapa sastrawan kampus memiliki posisi yang cukup penting dalam sastra Indonesia. Posisi ini dipengaruhi oleh produktivitas karya, promosi dan publikasi, serta jejaring yang dimiliki. Semakin banyak karya yang dihasilkan dan dipublikasikan secara massif di berbagai media, penulis karya tersebut akan semakin dikenal oleh masyarakat.
\end{abstract}

Kata Kunci: profil, sastrawan kampus, sosiologi pengarang

\section{THE PROFILES OF CAMPUS WRITERS OF YOGYAKARTA STATE UNIVERSITY}

\begin{abstract}
A campus functions not only as a bridge to achieve higher education, but also a vehicle for developing individual competencies, including those in the field of literature. Young writers or those who grow up when studying in a college or campus are usually called campus writers. This study aims to identify social background, ideology, authorship professionalism, and social position of campus writers of Faculty of Languages and Arts (FLA), Yogyakarta State University (YSU), in the Indonesian literature. The study used a phenomenological approach with a researchfocus on
\end{abstract}


campus writers who are active in writing prose (novels and short stories) at FLA, YSU. The findings are as follows. First, most of the YSU campus writers come from the Javanese ethnic group. They are mostly male writers. Generally, they family backgrounds related to the field of education. Second, they generally prefer to pay attention to things that are often neglected in life to be written in their works. Idealism about authentic values that collide with the community's pragmatism values becomes powerful energy encouraging them to write. Third, they generally do not make writing their main profession. Writing is a side job. They do not depend on certain patronage. Fourth, some of them have quite important positions in the Indonesian literature. This position is influenced by the productivity of works, promotions and publications, and networks. The more they produce works and publicly publish them in various media, the more they are recognized by the public.

Keywords: profiles, campus writers, sociology of writers

\section{PENDAHULUAN}

Kampus berfungsi tidak hanya sebagai jembatan untuk mencapai pendidikan tinggi, namun juga wahana untuk mengembangkan kompetensi individu. Saat masih berbentuk Institut Keguruan dan Ilmu Pendidikan (IKIP) Yogyakarta, Universitas Negeri Yogyakarta mencatat sejarah sebagai salah satu Perguruan Tinggi Negeri di Yogyakarta yang memiliki beberapa sastrawan -Prof. Dr. Suminto A Sayuti, Ahmadun Yosi Herfanda, dan almh. Endang Susanti Rustamaji, Eddy Lyrisacra, Budi Nugroho, Marjudin Sueb, Purwadmadi Atmadipurwa, Muhammad Fuad Riyadi, Edi Romadon, Andoyo Suliantoro, Choen Supriatmi, dan Wicahyanti Rejeki- yang bergulat dan membesarkan dirinya sebagai sastrawan di kampus.

Dengan adanya Keputusan Presiden RI No. 93 Tahun 1999, IKIP Yogyakarta menjadi universitas. Perubahan status ini membawa kemajuan yang cukup signifikan. Jurusan Pendidikan Bahasa dan Sastra Indonesia di Fakultas Bahasa dan Seni, misalnya, memiliki program studi Sastra Indonesia. Kurikulum di Sastra Indonesia FBS UNY juga berupaya untuk menyesuaikan kepentingan masyarakat dan stakeholder pengguna lulusan. Salah satu output yang hendak dikembangkan dan menyesuaikan tuntutan zaman yang terus berkembang inilah, maka JPBSI FBS UNY membekali mahasiswa dengan sejumlah mata kuliah kepenulisan atau proses kreatif.

Sastrawan kampus dari FBS UNY tercatat memiliki track record menulis yang cukup baik. Eko Triono dari JPBSI, misalnya, tercatat sebagai saslah satu sastrawan kampus yang sampai saat ini terus produktif menghasilkan karya. Beberapa karya Eko Triono antara lain Agama Apa yang Pantas bagi Pohon-Pohon (2016). Kun Anindito, misalnya, cerpennya pernah mendapatkan penghargaan dalam kompetensi menulis yang diselenggarakan oleh Rohto dan telah menerbitkan kumpulan cerpen Sebelum Telepon Berdering (2013). Herlina Tiens tercatat sebagai sastrawan perempuan yang sukses berkarya, seperti yang ter- 
lihat dalam Garis Tepi Seorang Lesbian, Koella, Rebonding, dll.

Sastrawan kampus yang bertumbuh di FBS UNY sejauh ini belum dipetakan, bagaimana proses menulisnya, latar kepenulisannya, apakah faktor sosial kebudayaan dan pendidikan masing-masing penulis memengaruhi jenis atau karakter tulisannya, serta yang tak kalah penting adalah bagaimana posisi sosial sastrawan kampus dalam khasanah sastra Indonesia. Pemetaan sastrawan kampus ini memiliki urgensi yang cukup penting bagi eksistensi JPBSI FBS UNY karena dapat bermanfaat sebagai bentuk evaluasi terhadap kurikulum yang dibuat. Berdasarkan latar belakang inilah, maka penelitian ini menggunakan pendekatan sosiologi pengarang, yang difokuskan pada upaya untuk mengidentifikasikan latar belakang sosial sastrawan kampus, mengetahui bagaimana ideologi sosialnya, menjelaskan profesionalisme kepengarangannya, dan memetakan posisi sosial sastrawan kampus dalam khasanah sastra Indonesia.

Beberapa penelitian tentang sosiologi pengarang sudah pernah dilakukan oleh Masruroh seperti yang terlihat dalam "Tinjauan Sosiologis Pengarang Novela Adinda Kulihat Beribu-Ribu Cahaya di Matamu Karya Ayu Sutarto" (Masruroh, 2013), Anis Handayani dalam "Novel Pudarnya Pesona Cleopatra Karya Habiburrahman el Shirazy" (2009), Periventa dalam "Pengaruh Latar Belakang Pengarang dalam Cerpen "Nemuri Usagi"karya Hoshi Shinichi" (2017). Namun, ketiga penelitian itu belum menganalisis dengan sosiologi pengarang secara tepat. Analisis Masruroh dan Handayani cenderung mencampuradukkan antara sosiologi peng- arang, karya, dan pembaca. Sementara, Periventa mencampurkan kajian struktural dengan sosiologi pengarang.

Sosiologi pengarang merupakan kajian sosiologis dalam karya sastra. Wellek dan Warren memetakan kajian sosiologis terhadap karya sastra dalam tiga wilayah. Pertama, sosiologi pengarang. Kedua, sosiologi karya sastra. Ketiga, sosiologi pembaca dan dampak sosial karya (2016:111). Sosiologi pengarang berkaitan dengan dasar ekonomi produksi sastra, latar belakang sosial, status pengarang, dan ideologi pengarang yang terlihat dari berbagai kegiatan pengarang di luar karya sastra.

Senada dengan Wellek dan Warren, Junus menjelaskan ada enam faktor yang berkaitan dengan sosiologi pengarang (1986:80). Faktor pertama adalah asal sosial. Kedua, kelas sosial. Ketiga, seks atau jenis kelamin. Keempat, umur. Kelima, pendidikan. Keenam, pekerjaan. Khusus untuk aspek sosial, Junus mengidentifikasikannya sebagai latar belakang sosial penulis sebelum menggeluti profesinya sebagai penulis, sedangkan kelas sosial berkaitan dengan asal status sosialnya, misal: orang desa atau kota, dari kelompok mayoritas atau minoritas.

MerujukIan Watt, Damono(1984:3) menyampaikan bahwa sosiologi pengarang berkaitan erat dengan bagaimana cara si pengarang mendapatkan mata pencahariannya, apakah memiliki patron, dari masyarakat langsung, atau dari kerja rangkap. Selain itu, sosiologi pengarang juga mencermati profesionalisme kepengarangan seorang penulis: apakah menulis merupakan profesi utama atau sambilan baginya. Selanjutnya, sosiologi pengarang berkaitan dengan 
bagaimanakah bentuk masyarakat yang dituju oleh pengarang.

Dari penjelasan di atas, dapat disimpulkan bahwa telaah sosiologi pengarang adalah telaah yang lebih menitikberatkan perhatiannya pada aspek pengarang, dari segi sosialnya. Hal ini meliputi latar belakang sosial, ideologi sosialnya, dan profesionalitasnya dalam kepengarangan. Karya pengarang ditelaah namun sebatas ephinomenon atau gejala ke dua. Inilah yang membedakan sosiologi pengarang dengan sosiologi karya sastra atau sosiologi pembaca.

Tujuan penelitian ini adalah: (1) mengidentifikasikan latar belakang sosial sastrawan kampus FBS UNY, (2) menjelaskan ideologi sosial sastrawan kampus FBS UNY, (3) menjelaskan profesionalisme kepengarangan sastrawan kampus FBS UNY, dan (4) memetakan posisi sosial sastrawan kampus FBS UNY dalam khasanah sastra Indonesia.

\section{METODE}

Penelitian ini adalah penelitian kualitatif fenomenologis dengan fokus penelitian pada sastrawan kampus di Fakultas Bahasa dan Seni dengan menggunakan pendekatan sosiologi pengarang. Sastrawan kampus yang dipilih sebagai subjek penelitian ini dipilih secara purposive, dengan kriteria sebagai berikut: (1) pernah tercatat sebagai mahasiswa di Fakultas Bahasa dan Seni sejak tahun 1999 dan sesudahnya; (2) menggeluti dunia kepenulisan prosa; (3) berproses menulis prosa ketika masih tercatat sebagai mahasiswa atau sesudahnya; dan (4) memiliki karya dan prestasi.

Sastrawan kampus yang menjadi subjek dalam penelitian ini antara lain:
(1) Herlina Tiens (Prodi PBSI), (2) Kedung Dharma Romansha (Prodi Sastra Indonesia), (3)Eko Triono(Prodi PBSI), (4) Kun Anindito (Prodi Sastra Indonesia), (5) Muhammad Qadafi (Prodi Sastra Indonesia).Teknik pengambilan data yang digunakan dalam penelitian ini antara lain wawancara, penelusuran dan kajian karya sastrawan kampus, serta penelusuran berita di berbagai media. Teknik analisis data yang digunakan dalam penelitian ini adalah teknik deskriptif kualitatif.Jenis validasi yang digunakan dalam penelitian ini adalah validitas konten dan validitas konstruk. Jenis reliabilitas data yang digunakan dalam penelitian ini ada dua. Reliabilitas intrarater dan interrater.

\section{HASIL DAN PEMBAHASAN \\ Latar Belakang Sosial Sastrawan Kampus FBS UNY}

Latar belakang sosial pengarang berkaitan dengan kehidupan pengarang sebagai makhluk sosial yang berinteraksi dengan masyarakat, seperti asal atau tempat dibesarkannya, garis keturunannya, riwayat pendidikannya, lingkungan pergaulannya, pekerjaannya, dan sebagainya. Latar belakang sosial pengarang sangat mempengaruhi karya yang diciptakannya.

Lima sastrawan kampus FBS UNY yang diteliti berasal dari daerah yang berbeda-beda, yaitu Klaten, Cilacap, Salatiga, Indramayu, dan Ngawi. Meskipun berasal dari daerah yang berbedabeda, mereka menjalani proses kreatif penulisan di Yogyakarta ketika kuliah di jurusan PBSI FBS UNY. Mereka mulai mengenal dunia penulisan ketika kuliah dengan saling belajar antarmahasiswa yang memiliki minat menulis 
dan beberapa terlibat dalam komunitas menulis.

Keterlibatan dalam komunitas penulis dimiliki oleh semua sastrawan yang diteliti, kecuali Herlinatiens. Sementara itu, Eko Triono terlibat dalam Komunitas alumni Akademi Penulisan Novel DKJ dan Komunitas KUD. Komunitas KUD ini hanya berisi sembilan anggota paten, termasuk Muhammad Qadhafi. Kedung tergabung dalam komunitas Rumah Poetika, Rumah Lebah, dan Rumah Kami.

Beberapa sastrawan seangkatan Kun Andyan Anindito pada masa kuliah mendirikan Komunitas Malam Perjamuan Sastra (MPS). Pertemuannya rutin setiap Jumat malam di PKM FBS UNY. Di komunitas ini mereka melahirkan sebuah antologi puisi bersama yang berjudul Ia Terbangun di Tahun yang Belum Tercatat Kalender.

Setelah lulus dari jurusan PBSI FBS UNY, para sastrawan ini memiliki aktivitas yang berbeda-beda. Kun Andyan Anindito dan Eko Triono melanjutkan S2 di prodi Pendidikan Bahasa Indonesia Universitas Sebelas Maret Surakarta (UNS) dan dan mengajar Bahasa Indonesia di universitas swasta. Selain mengajar Bahasa Indonesia, Eko Triono juga mengajar Penulisan Kreatif di Universitas Muhammadiyah Yogyakarta (UMY). Mereka berdua juga terlibat dalam penerbitan. Kun Andyan Anindito sebagai pemimpin redaksi di Penerbit Gambang Buku Budaya Yogyakarta. Eko Triono sebagai editor lepas di beberapa penerbit, seperti penerbit Quark, BasaBasi, Gambang, dan PT Nun Media.

Muhammad Qadhafi dan Kedung Darma Romansa melanjutkan S2 di UGM prodi Sastra dan lulus tahun
2016/2017. Qadhafi juga sebagai editor di jogjareview.net dan jurnal Poetika, UGM. Setelah lulus S2, ia dipercaya sebagai peneliti di PKKH, UGM. Sementara itu, Kedung Darma Romansa beraktivitas sebagai dosen di Jogja Film Academy dan guru pelatihan jurnalistik program unggulan di MTs Ali Maksum Yogyakarta. Latar belakang sosial pengarang sangat berpengaruh dalam berkarya. Sebagai contoh adalah Kedung Darma Romansha. Selain menekuni dunia tulis menulis (sastrawan), Kedung juga aktif dalam dunia teater. Faktor interaksi dengan kakeknya tidak bisa dipisahkan dari profesi kepenulisannya saat ini. Melalui Pradana (2014), Kedung mengaku sejak usia lima tahun sudah menyukai pertunjukan wayang, dan terbiasa menonton wayang bersama kakeknya.

Herlinatiens sempat berkarir sebagai presenter di Jogja TV Yogyakarta dan DAI TV di Jakarta. Herlina juga menjadi Staf Ahli Yayasan Umar Kayam di Yogyakarta dan Konsultan IT di AD!JAVA Pathnership di Yogyakarta sampai sekarang. Setelah lulus S1, Herlinatiens mengambil kuliah S2 prodi Ilmu Religi dan Budaya di Sanata Darma.

Sastrawan kampus memiliki latar belakang keluarga yang beragam. Profesi orang tua mereka sebagaian besar adalah pendidik, kecuali Kedung Darma (Falah, 2017). Tingkat pendidikan orang tua juga beragam, mulai dari lulusan Sekolah Rakyat sampai S3 (program doktoral).

\section{Ideologi Sosial Sastrawan Kampus FBS UNY}

Ideologi memiliki banyak pengertian. Kadang ideologi disangkutpautkan 
dengan dogma, kadang berkonotasi dengan sesuatu yang politis, model berpikir yang dominan, atau sesuatu yang dijauhkan dari status quo (Gerring, 1997:597). Sedangkan dalam perspektif sosiologi pengarang, ideologi sosial pengarang adalah pemikiran pengarang yang merupakan hasil dari proses interaksi sosialnya dengan lingkungan atau milieu mereka. Ideologi sosial pengarang ini dapat dipengaruhi oleh berbagai hal, seperti komunitas, kelompok sosial pengarang, atau rekan seprofesinya. Hasil berinteraksi sosial dengan lingkungan mereka inilah yang kemudian memengaruhi karya-karyanya.

Pengarang memiliki perhatian yang berbeda terhadap segala aspek kehidupan. Herlina Tiens, misalnya. Berdasarkan wawancara dengan pengarang alumnus Jurusan Pendidikan Bahasa dan Sastra Indonesia yang lulus tahun 2006 ini mengatakan bahwa dia menaruh perhatian kepada hal yang dilupakan atau luput dari perhatian orang-orang. Herlina mencontohkan kaum lesbian. Inilah yang menginspirasinya menulis novel Garis Tepi Seorang Lesbian (terbit tahun 2003).Di tahun terbitnya novel tersebut, isu lesbianisme dalam karya sastra di Indonesia masih dianggap tabu, belum banyak digarap oleh sastrawan.

Dalam novel Herlina, lesbianisme dianggap sebagai sesuatu yang gifted oleh Tuhan. Hal yang 'normal', seperti halnya orientasi seksual yang sesuai dengan kaidah heteronormatif. Namun sayang, keberadaannya dalam masyarakat dianggap tabu untuk diketahui atau ditampakkan. Keberadaannya dianggap sebagai 'penyakit jiwa'. Pemikiran ini tampak dalam kutipan novel Garis Tepi Seorang Lesbian berikut.
Sudah aku katakan, aku melakukannya tanpa sadar, alamiah saja, sebuah penggabungan dua gender yang berbeda, dalam diriku. Ya, aktifis-aktifis feminis mengatakannya transgenderisme. Ini sesuatu yang normal dan wajar. Aku tidak memandang kelesbianku sebagai aib, dosa, penyakit, atau suatu bentuk dari sakit jiwa, atau bahkan karena kekecewaan yang dalam dari seorang laki-laki. It's given. Pemberian Tuhan. Jangan menjadi homofobia, Gita. Jangan menganggap kami sebagai pengusung panji-panji dekadensi moral. Kami adalah bagianmu.

Kami ada banyak, tersebar dan ada di mana-mana. Kau tahu tentang cerita penyair wanita di jaman Yunani? Sappho. Tidak perlu jauhjauh, kau pernah mendengar tentang dua orang lesbian di Jakarta yang menikah di depan umum, kira-kira di awal tahun 1981? Itu hanya sebuah kasus, sebenarnya ada banyak dari kami yang melakukannya. Dua hari yang lalu seorang butchie menikahi femme nya di daerah Bogor. Dan aku sudah melakukannya juga, dengan Rie. Rie Shiva Ashvagosha. (Herlinatiens, 2003:11-12).

Apa yang dilakukan oleh Herlinatiens dalam novelnya itu sebenarnya lebih bertujuan untuk menyadarkan bahwa kaum dengan orientasi seksual yang dianggap 'menyimpang' itu ada. Mereka juga memiliki hak dan kemampuan yang sama. Kaum lesbian pun memiliki perasaan. Oleh karena itu, perundungan terhadap kaum LGBT, sejatinya merupakan persoalan kemanusiaan. 
Salah satu sastrawan kampus produktif dari Fakultas bahasa dan Seni Universitas Negeri Yogyakarta lainnya adalah Eko Triono. Lahir dan besar dari keluarga guru, tulisan Eko cenderung lebih kaya tema. Eko banyak berbicara dalam karya-karyanya. Dari soal politik, hingga sesuatu yang bernilai filosofis-psikologis. Salah satu karya Eko yang mendapatkan apresiasi dari publik adalah "Agama Apa yang Pantas untuk Pohon-Pohon" (2016). Cerpen ini mendapatkan penghargaan sebagai lima prosa terbaik dalam Anugerah Kusala Sastra Khatulistiwa 2016 (https://hot.detik.com/book/d3313174/ini-5-besar-kusala-sastrakhatulistiwa-2016). Berikut adalah pemikiran Eko mengenai potensi agama dalam konflik manusia yang terdapat dalam cerpennya.

Selain pertanyaanmu yang tibatiba melompat: "Agama apa yang pantas bagi pohon-pohon?"

"Kenapa memangnya?"

"Bukankah berbagai pohon dapat tumbuh di tempat yang sama dengan damai?"

"Ya. Kenapa?"

"Ini soal perasaan. Kau tidak akan mengerti."

Jujur, aku tak tahu harus komentar apa. Kurendahkan sandaran 150 dan mencoba berpikir pada kursi nomor 11, di sebelahmu ini. Hujan pun semakin menembaga.

Dan lampu-lampu lalu lintas memberitahu lagi, pernikahan kalian memang berbeda agama. Kemudian, berpisah. Zafin dibawa oleh ayahnya.

Bus berhenti sejenak di kota G.
"Aku mengira, seandainya pohon-pohon beragama, hewan-hewan berideologi, dan para jin dan tuyul membuat undang-undang, mendirikan partai, mengendalikan kekuasan, hukum, dan politik, masihkah kita disebut sebagai manusia?"

(Triono, Kompas, 28 April 2013)

Sebagai seorang sastrawan yang berinteraksi dan menjadi saksi atas apa yang terjadi di sekitarnya, Triono pun merekam kejadian yang up to date. Aksi terorisme di Mako Brimob pada 9 Mei 2018 terepresentasi dalam cerpen "Kesunyian Ini, Kambing Sekali Rasanya" (Tribun Jabar, 20 Mei 2018). Dalam cerpennya itu, Triono juga memberikan kritik terhadap kedirian manusia yang cenderung mudah kalap dalam bertindak ketika dia memanfaatkan kekuasaan atau jabatan yang dimilikinya. Hukum menjadi pelindung bagi oknum polisi untuk bertindak sewenangwenang saat melakukan interogasi. Pemikiran filosofis ideal Triono mengenai kejiwaan manusia, tampak dalam kutipan cerpen berikut.

Lalu, kepulan asap, sekejap pada ketinggian melintasi puncak hotel dan pepohonan. Suara ambulans menderu. Orang-orang menjerit. Tetapi aku, jauh di dalam jiwaku, makin merasa sunyi sedemikian rupa dan sehingga entah.

Polisi tahi lalat, yang memegang lenganku, berkata di sisi kanan telinga, "Bagaiman acaranya memasukkan bom ke perut kambing?"

"Aku tidak tahu," jawabku menatap sisa asap dan kegelisahan. 
"Mungkin seperti masuknya sunyi ke dalam hati manusia."

Dap!

Dia tendang bokongku pakai lutut hukum, sekuat-kuatnya. (Triono, Tribun Jabar, 20 Mei 2018)

Seperti halnya Herlina Tiens, Romansha tertarik untuk mengangkat hal keseharian yang luput dari perhatian. Romansha memiliki perhatian terhadap isu-isu sosial yang ada di sekitarnya. Besar di daerah Indramayu yang memiliki karakteristik masyarakat yang khas, Romansha merekam isu-isu sosial dalam karyanya, antara lain Telembuk dan Kelir Slindet. Bagi Romansha, menulis adalah tanggung jawab sosialnya. Oleh karena itu, tak mengherankan bila karya-karyanya banyak bicara tentang persoalan sosial kaum bawah (kemiskinan, kebodohan, kriminalitas), pelacuran, ataupun konflik horizontal (Lestari, Anisa \& Femy, 2017).

Isu-isu sosial memang menjadi energi yang menarik untuk dibahas semua pengarang. Anindito, salah satu sastrawan kampus juga mengangkat isu ini dalam karya-karyanya.Seperti halnya Andindito, Qadhafi tertarik untuk mengangkat isu-isu yang kadang terkesan sepele namun bermakna bagi kehidupan. Kegelisahan Qadhafi mengenai moralitas, misalnya, dapat ditemukan dalam cerpennya yang berjudul "Anjing Kebiri", salah satu cerpen karya Qadhafi yang dihimpun dalam antologi Kastagila dan 16 Cerpen Lainnya (Penerbit Gambang, 2015).

"Tetapi kau juga perlu tahu, sudah 39 hari lalu Kades kades itu mati mengenaskan. Tubuhnya tercabik-cabik di dalam kamar. Me- ninggalkan bau. Sama sekali bukan bau anyir darah, melainkan bau pesing memualkan.

Aku tahu betul duduk kematiannya. Waktu itu purnama. Ketika sedang khusuk-khusuknya bertapa, ia diserbu gerombolan anjing tak berkemaluan yang memang telah lama bersekongkol mencabik nyawanya. Cahaya lilin-lilin menggelayut, berkilauan pada beberapa bait dinding kayu kamarnya, kemudian pejam bersama lesapnya nyawa sang Kepala Desa." (Qadhafi, 2015).

Bagisaya, segala yang bisa dipikirkan dan dihayati, itu bisa jadi ide. Baik yang dianggap sepele maupun penting. Biasanya, ide saya bermula dari kegelisahan terhadap sesuatu. (wawancara dengan Qadhafi, 1/05).

Herlina, Qadhafi, Kedung Dharma, Eko Triono, dan Anindito merupakan representasi intelektual muda yang tertarik kepada isu-isu social. Ideologi mereka yang selalu berkaitan dengan nilai-nilai otentisitas dalam kehidupan menjadi penggerak dalam karya-karyanya. Oleh karena itu, mereka bisa dengan mudah berpindah dari satu tema ke tema cerita yang lain. Pada suatu karya, mereka bicara tentang idealisme tentang keluarga. Pada karya yang lain mereka bicara tentang pendidikan, kesetaraan gender, keadilan, atau demokrasi. Pergulatan-pergulatan penulis muda (sastrawan kampus) dengan lingkungan sosial akan banyak menyajikan idealisme. Idealisme ini merupakan bentuk tegur sapa sekaligus pertanggungjawaban mereka selaku "makhluk yang terberkahi dengan kemampuan menya- 
lakan kesadaran" bagi masyarakat di sekitar mereka.

\section{Profesionalisme Kepengarangan Sas- trawan Kampus FBS UNY}

Semua sastrawan kampus FBS UNY memiliki prestasi dan produktivitas berkarya yang berbeda-beda. Eko Triono adalah sastrawan kampus FBS yang paling banyak memiliki penghargaan dan karya. Dalam lembaga formal, Eko juga dipercaya sebagai pendamping Bengkel Bahasa dan Sastra Indonesia di Balai Bahasa DIY dari tahun 2016 sampai sekarang. Pada tahun 2013-2014 ia juga dipercaya menjadi tenaga lepas asisten Deputi Kreativitas Pemuda, Deputi Pemberdayaan Pemuda, Kementerian Pemuda dan Olahraga RI.

Meskipun memiliki produktivitas yang tinggi, Eko Triono mengaku tidak menjadikan menulis sebagai profesi utama. Ia mengatakan bahwa profesi utamanya adalah pengajar. Pengalaman mengajarnya adalah pengajar tidak tetap MKU Bahasa Indonesia di Universitas Mercu Buana dan Universitas Muhammadiyah Yogyakarta. Di Universitas Muhammadiyah Yogyakarta ia juga mengajar Penulisan Kreatif.

Sastrawan kampus FBS UNY yang tidak kalah produktif adalah Kedung Darma Romansha. Dilihat secara kuantitas, tulisan Kedung memang tidak sebanyak Eko Triono, tetapi karya-karya Kedung banyak didiskusikan bahkan diteliti. Sebut saja dalam hal ini adalah karyanya yang berupa novel Kelir Slindet (2014) dan Telembuk (2017). Selain menulis novel, kedung juga menulis puisi. Kumpulan puisinya yang telah diterbitkan adalah Uterus (2015) dan Masa Lalu Terjatuh dalam Senyumanmu
(2018). Ia juga meraih beberapa penghargaan terkait dengan penulisan puisi. Kedung Darma Romansha juga dikenal sebagai pemain teater dan pemain film. Ia telah bermain sebagai pemeran pendukung di sejumlah film layar lebar dengan berbagai peran, sebut saja sebagai Soebadio dalam film "Soekarno" besutan sutradara Hanung Bramantyo (2013), sebagai Ustadz Juki dalam film "Mata Tertutup" karya sutradara Garin Nugroho (2011), dan pemeran pendukung dalam film "Soegija", "Sang Kyai", "Jokowi", dan "Ainun Habibi" (Pradana, 2014). Namun, menulis bagi Kedung bukan profesinya yang utama. Menulis baginya merupakan tanggung jawab sosial.

Kun Andyan Anindito dan $\mathrm{Mu}-$ hammad Qadhafi menjadikan menulis ini sebagai hobi. Kun Andyan Anindito pernah meraih tiga penghargaan dalam penulisan pada tahun 2013-2014 dan menerbitkan sebuah karya kumpulan cerpen Sebelum Telepon Berdering (2014). Setelah tahun 2014, ia belum berkarya lagi. Kondisi yang sama terjadi pada Muhammad Qadhafi. Sebagaimana diungkapkan dalam wawancara, masa paling produktifnya menghasilkan karya adalah antar atahun 2012-2013, tepatnya setelah bebas teori dan bebas dari tugas sebagai ketua HIMA. Herlina sangat produktif berkarya dari tahun 2003-2012, tetapi karyanya belum terbit lagi setelah itu.

Kevakuman karya dalam beberapa tahun bagi Kun Andyan Anindito, Muhammad Qadhafi, dan Herlinatiens dalam menulis sastra agaknya dipengaruhi oleh motivasinya menulis bukan dijadikan sebagai profesi utama. Mereka masih terlibat dalam dunia tulis menulis, seperti Kun Andyan Anindito 
terlibat dalam penerbitan, Muhammad Qadhafi dalam pengelolaan jurnal di UGM, tetapi tidak spesifik menulis sastra sebagaimana mereka lakukan di masa-masa masih duduk di bangku kuliah.

\section{Posisi Sosial Sastrawan Kampus FBS UNY dalam Jagat Sastra Indonesia}

Sastrawan kampus yang besar di Universitas Negeri Yogyakarta umumnya memiliki komunitas di kampus mereka. Ikatan yang kuat antara $\mathrm{Mu}-$ hammad Qadhafi dan almamaternya terlihat dari perannya dengan KMSI atau Keluarga Mahasiswa Sastra Indonesia. Keberadaan KMSI di kampus ini cukup vital.Komunitas sastra di kampus inilah yang membuat karyakarya sastrawan kampus lebih dikenal, khususnya di lingkungan akademik. Novel karya Muhammad Qadhafi Kastagila (2015) dan Sebelum Telepon Berdering (2014) karya Kun Anindito bahkan pernah dibahas dalam satu diskusi "Malam Susastra" di kampus dengan kumpulan cerpen Kakek karya Eko Triono.

Jejaring komunitas yang dimiliki Eko Triono tidak hanya sebatas di kampus Universitas Negeri Yogyakarta. Buku-buku yang telah dihasilkannya juga tidak hanya dibahas di Yogyakarta, tapi juga di luar Yogya, seperti Malang. Buku Agama Apa yang Pantas bagi PohonPohon masuk dalah sepuluh besar karya terbaik dalam Kusala Sastra Khatulistiwa Award (www. hot.detik.com). Buku ini juga mendapatkan penghargaan dari Balai Bahasa Yogyakarta di tahun 2017 (http://jogja.tribunnews. com/2017/11/09/inilah-para-pemenang-penghargaan-bahasa-dan-sastratahun-2017). Bedah buku adalah cara yang cukup efektif untuk mengenalkan karya sastrawan-sastrawan muda ke masyarakat. Di sini, peran komunitas kepenulisan menjadi penting. Komunitas kepenulisan dapat menjadi sarana untuk mengenalkan karya-karya mereka.

Kemunculan novel Herlina Tiens, Garis Tepi Seorang Lesbian dianggap membawa semangat pendobrakan terhadap nilai-nilai yang selama ini dianggap tabu, atau ditutupi oleh masyarakat. Oleh karena itu, tidak mengherankan, namanya masuk dalam sastrawan perempuan Indonesia yang dianggap berani mengungkapkan hal yang tabu dalam karya sastra. Gaya atau teknik penulisan novelnya juga cenderung berani. Persis seperti pendahulunya, Ayu Utami.

Keberanian Herlina dalam menyampaikan cerita yang tidak biasa di eranya, membuat namanya masuk dalam jajaran sastrawan perempuan Indonesia yang cukup dikenal di tingkat nasional. Novel Garis Tepi Seorang Lesbian bahkan diklaim sebagai salah satu novel best seller terbitan Diva Press (penerbit yang menerbitkan novel Herlina). Keberadaan Herlina disamakan dengan sastrawan perempuan yang pada awal 2000an muncul dan mewarnai jagat sastra Indonesia, seperti Dee Lestari, Nova Riyanti Yusuf, Fira Basuki, Dinar Rahayu.

Bila dilihat dari latar belakang keluarga atau masa kecil Kedung Dharma, yang bersangkutan sangat jauh dari budaya berkesenian. Kuliah di Universitas Negeri Yogyakarta semakin mendekatkannya pada dunia seni. Saat masih tercatat sebagai mahasiswa Sastra Indonesia, minatnya terhadap sastra semakin menguat. Beberapa teman 
komunitas berkeseniannya antara lain seperti Raudal Tanjung Banua, Sunlie Thomas Alexander, Saut Situmorang, Indrian Koto, Joni Ariadinata, Iman Budi Santosa.

Pada perkembangan proses kreatifnya, Kedung Dharma meluaskan daya berkreatifnya dengan merambah dunia prosa dan perfilman. Beberapa novel yang pernah ditulisnya antara lain $\mathrm{Ke}$ lir Slindet (2014, Gramedia) dan Telembuk (2017, Indie Book Corner). Kedua novel ini mendapatkan sambutan yang cukup hangat di dunia akademik. Terbukti dengan ditemukannya berbagai kajian, baik tesis maupun skripsi, yang membahas novel Kedung Darma tersebut.

\section{SIMPULAN}

Sastrawan kampus Universitas Negeri Yogyakarta memiliki peran yang cukup strategis dalam khasanah sastra Indonesia. Keberadaan penulis-penulis ini mematahkan mitos bahwa kemampuan menulis adalah soal genetis atau pun bakat. Permasalahan dalam kehidupan menjadi energi terbesar bagi sastrawan kampus untuk menulis. Menulis bagi sastrawan kampus masih dianggap sebagai tanggung jawab sosial atau hobi, dan belum sebagai profesi utama. Sastrawan kampus umumnya tidak bergantung pada patronase tertentu. Posisi sosial sastrawan di masyarakat dipengaruhi oleh produktivitas karya, publikasi, promosi, serta jejaring yang dimiliki.

\section{UCAPAN TERIMA KASIH}

Penulis mengucapkan terima kasih kepada Fakultas Bahasa dan Seni Universitas Negeri Yogyakarta yang telah memfasilitasi penelitian. Selain itu, penulis juga mengucapkan terima kasih kepada pembaca ahli dari Jurnal Litera yang telah memberikan saran untuk kelayakan artikel ini.

\section{DAFTAR PUSTAKA}

Agnes, T.. 2016. "Ini 5 Besar Kusala Sastra Khatulistiwa 2016" dalam https://hot.detik.com/book/d3313174/ini-5-besar-kusala-sastrakhatulistiwa-2016 diakses 21 April 2018.

Damono, SD.. 2003. Sosiologi Sastra. Jakarta: Pusat Pembinaan dan Pengembangan Bahasa.

Falah, F. 2017. Ideologi dan Kelas Sosial Pengarang dalam Novel Matinya Sang Penguasa Karya Nawal el Sadawi: Kajian Sastra Marxis. Jurnal Nusa, 12 (2) Tahun 2017.

Gerring, J. 1997. "Ideology: A Definitional Analysis" dalam Political Research Quarterly Vol. 50 No. 4 (December, 1997).

Handayani, A. 2009. Novel Pudarnya Pesona Cleopatra Karya Habiburrahman el Shirazy (Tinjauan Sosiologi Sastra). Skripsi. Universitas Sebelas Maret Surakarta.

Herlinatiens. 2003. Garis Tepi Seorang Lesbian. Yogyakarta: Galang Press.

Junus, U.. 1986. Sosiologi Sastera: Persoalan Teori dan Metode. Kuala Lumpur: Dewan Bahasa dan Pustaka.

Lestari, ML., Anisa A. dan Femy F. 2017. Hubungan Aspek Sosiologis Pengarang dengan Unsur Intrinsik dalam Novel Nijuushi No Hitomi Karya Sakae Tusbai. Jurnal Janaru Saja. VI (1) Mei 2017.

Masruroh, W. 2013. Tinjauan Sosiologis Pengarang Novela Adinda Kulihat Beribu-Ribu Cahaya di Matamu 
karya Ayu Sutarto. Skripsi. Universitas Negeri Jember.

Pradana, RAR. 2014. Kedung Darma Romansha Hafal Kisah Pewayangan Sejak Kecil diakses dari http://jogja.tribunnews.com/2014/02/19/ kedung-darma-romansha-hafalkisah-pewayangan-sejak-kecil pada 21 April 2018.

Priventa, H. 2017. Pengaruh Latar Belakang Pengarang dalam Cerpen Nemuri Usagi karya Hoshi Shinichi (Kajian Sosiologi Sastra). Skripsi. Universitas Diponegoro, Semarang.
Qadhafi, M.. 2015. "Anjing Kebiri” dalam Kastagila dan 16 Cerpen Lainnya. Yogyakarta: Gambang.

Triono, E.. "Agama Apa yang Pantas Bagi Pohon-Pohon" dalam Kompas 28 April 2013.

Triono, E. "Kesunyian Ini, Kambing Sekali Rasanya" dalam Tribun Jabar, 20 Mei 2018.

Wellek, R. dan Warren, A. 2016. Teori Kesusastraan (terjemahan Melanie Budianta). Jakarta: Gramedia Pustaka Utama. 